\title{
Research
}

\section{Exploring Resilience and Transformability of a River Basin in the Face of Socioeconomic and Ecological Crisis: an Example from the Amudarya River Basin, Central Asia}

\author{
$\underline{\text { Maja Schlüter }}^{1,2}$ and Elke Herrfahrdt-Pähle ${ }^{3}$
}

\begin{abstract}
Water from the Amudarya River is a vital and strategic resource for semi-arid Uzbekistan because of its heavy reliance on irrigated agriculture. The Uzbek water management regime, however, has proven to be rather reluctant to adapt to changing environmental and socio-political conditions despite recent massive pressures caused by political, environmental, or donor-induced developments in the region. The aim of this paper is to explore reasons for the low adaptability of the Uzbek water sector and assess implications for the resilience of the Uzbek social-ecological system (SES). By analyzing past losses of resilience as well as first attempts at institutional change in land and water management, we identify drivers as well as structural factors and mechanisms that act as barriers for adaptation and transformation towards a more sustainable system. With the collapse of the Aral Sea fisheries and the basin-wide large scale soil salinization, the SES in the Amudarya River Basin has shifted to a new, less desirable regime. However, the high resilience of the social system is keeping it in its current undesirable state and further degrades its long-term resilience. Our analysis identifies reinforcing feedbacks caused by ecological dynamics, vested interests, and a patronage system that contribute to the resistance to change and keep the system locked in its current unsustainable state. These factors are rooted in the history of the SES in the river basin, such as the economic dependence on cotton and the state-centered management approach. The window of opportunity for significant changes of the larger scale institutional setting that might have been open after the breakup of the Soviet Union was or could not be used to achieve a transformation to more sustainable resources use. Measures aimed at an incremental improvement of the current situation are not sufficient to prevent further losses of resilience. Resilience and transformability of the larger scale SES (political, economic, and institutional settings) are needed to enable the smaller scales (regional and local water management) to adapt and change. However, we identified opportunities for change arising from the slow acceptance of bottom-up management institutions in the water sector and from the extensive restoration capacity of the ecosystems.
\end{abstract}

Key Words: Amudarya river basin; reform; resilience; transformation; Uzbekistan; water management

\section{INTRODUCTION}

The Uzbek water management regime in the Amudarya River Basin in Central Asia has proven to be rather resistant to change despite external and internal pressures caused by recent political, environmental, or donor-induced developments in the region. The independence of the riverine countries from the Soviet Union in 1991 was a major shock to the region. With the breakup of the Soviet Union the political and socio-economic settings on the river basin as well as national scales changed significantly. Moreover, the riverine countries face environmental degradation caused by historic overuse and mismanagement of the region's water resources. It strongly affects agricultural productivity and living conditions in the river basin. However, in all riverine countries adaptation of the water governance systems to the changed conditions has been very slow. Consequently the current water management institutions are becoming more and more inadequate to cope with the new situation. The

\footnotetext{
${ }^{1}$ Leibniz-Institute of Freshwater Ecology and Inland Fisheries, Berlin, Germany, ${ }^{2}$ Helmholtz Centre for Environmental Research (UFZ), Leipzig, Germany, ${ }^{3}$ German Development Institute (DIE), Bonn, Germany
} 
potential effects of climate change on the flow regime of the river might aggravate the situation even more.

The Amudarya is the largest river of Central Asia with an average annual runoff of $79 \mathrm{~km}^{3}$. It originates in the Hindukush and Pamir mountains in Tajikistan and Afghanistan, flows through the semi-arid Turan lowlands in Uzbekistan and Turkmenistan and drains into the Aral Sea (Figure 1). Water is a vital and strategic resource for all river basin countries because of their heavy reliance on irrigated agriculture. Today more than $90 \%$ of the region's water resources are used in the agricultural sector of the downstream countries Uzbekistan and Turkmenistan, with well-known negative consequences for riverine ecosystems and the Aral Sea. The ecological and social systems in the river basin are strongly linked by their water needs and by the institutions put in place to manage and use land and water resources. Measures to achieve sustainable resource use that maintains or enhances the resilience of the system thus have to take these interdependencies into account. Major shocks the river basin and particularly Uzbekistan had to cope with in recent years were: (1) the loss of the Aral Sea, particularly the collapse of its fisheries in 1982, (2) the breakup of the Soviet Union and independence of all river basin countries in 1991, and (3) a severe drought in the years 2000 and 2001. The low capacity of the current social-ecological system (SES) in the river basin to adapt to ongoing ecological and political changes seems to decrease the resilience of the SES to internal and external shocks, which became evident, for example, during the severe drought in 2000/2001.

The aim of this paper is to analyze the adaptability of the Uzbek water sector in the face of recent largescale political and environmental changes in the Amudarya river basin and to assess implications for the resilience of the Uzbek SES. Resilience is defined as both the capacity of a system to absorb shocks, and its capacity to learn from shocks and reorganize (Folke 2006). Adaptability is the capacity of actors to manage resilience and deal with current and future shocks (Walker et al. 2004). We are particularly interested in the potential of the recent crises that followed the shocks described to foster learning and adaptation in the water sector and transformation of the larger scale SES (Folke et al. 1998, Chapin et al. 2006). To this end we study the recent water sector reforms and their potential to increase the capacity of the water system to cope with political, institutional, and environmental change in other sectors, such as agriculture. We evaluate this potential by assessing their social, economic, and ecological outcomes, such as for example the degree to which the living standards of the population in the Uzbek part of the river basin have been maintained or improved and environmental degradation has been mitigated. Our analysis of the adaptability of the water sector reveals the need for transformation of the larger scale SES. We assess the potential for transformation by examining policies or institutions that could provide for fundamental structural change.

An assessment of resilience provides insights into the complex interdependencies across scales that determine the development and response options of the water management regime in Uzbekistan. This can support the identification of types of intervention and management measures that enhance its adaptability. Following the resiliencebased approach suggested by Walker et al. (2009) we treat the biophysical, social, and economic elements of our case study region as components of a single social-ecological system. Special emphasis is given to the role of linkages between ecological and social processes at different scales for shaping policies and development (Anderies et al. 2004, Folke et al. 2007) and determining the response of the SES to disturbance. In our analysis of recent behavioral and institutional changes in the water sector we distinguish between changes that take place within the logic of the current system and do not question its main functions (adaptation) and those that entail significant alterations of the system and its logic as such (transformation; Abel et al. 2006). We will argue that in the case of the Uzbek water sector, adaptation cannot happen without transformation of the larger scale SES. Such a new, transformed system would be characterized by a set of functions that differ from the ones provided by the current one. For example, it would no longer solely rely on irrigated agriculture as the backbone of the economy but rather develop a diverse set of economic activities.

After a short introduction to the context of the socialecological system in the river basin, we analyze dynamics and drivers of past and present resilience. We highlight major feedbacks between the agricultural and ecological systems that caused today's massive environmental degradation and the socio-economic context. Next we describe the 
Fig. 1. Map of the Amudarya River Basin. The grey shading indicates the catchment area of the Amudarya river (Siderius \& Schoumans 2008).

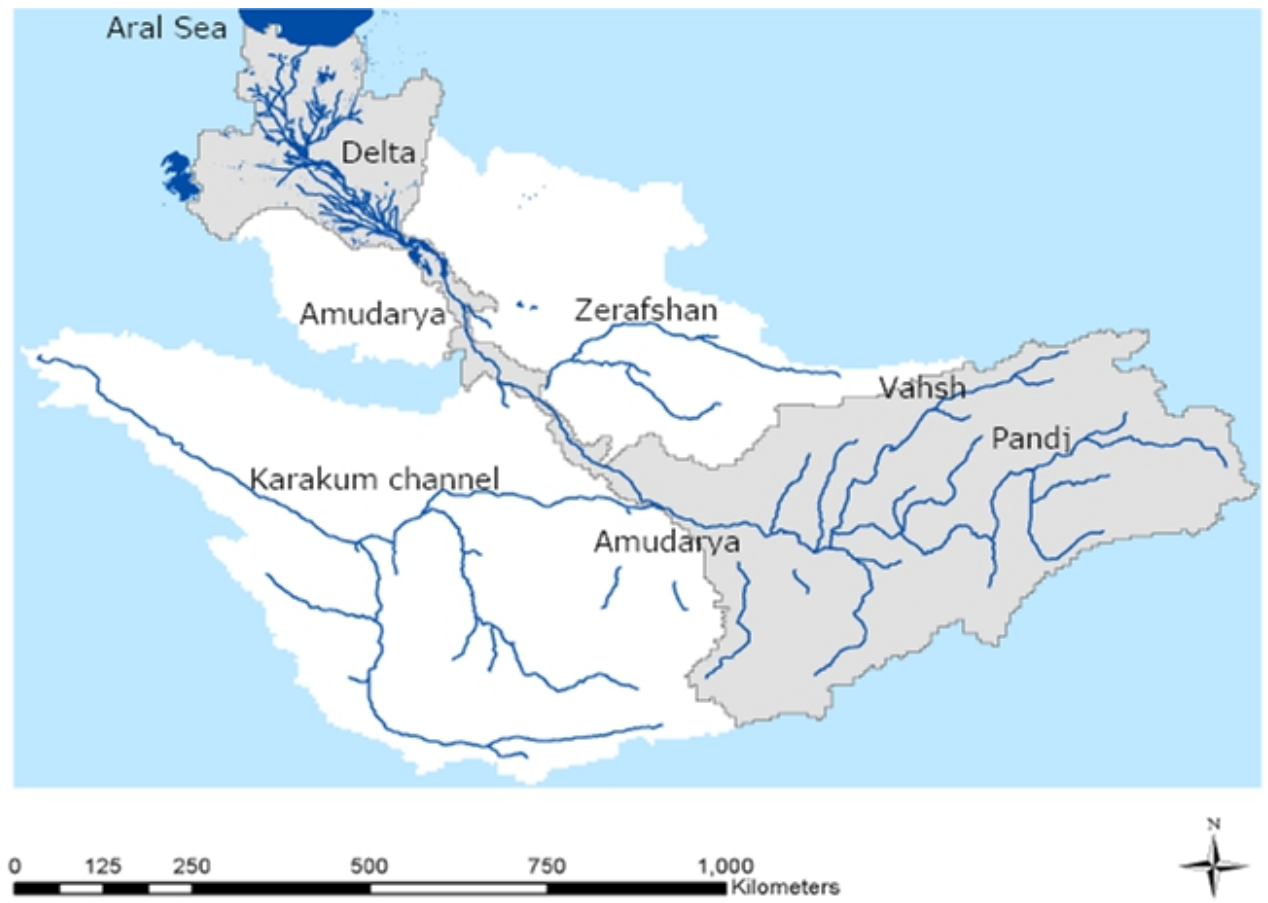

socio-economic reform process in the land and water sectors initiated after the breakup of the Soviet Union. This leads us to the investigation of today's resilience; particularly to the question of to what extent those recent institutional changes can be seen as institutional responses to past losses of resilience and recent shocks. We identify factors that explain the high resilience of parts of the social system and barriers for the transformation to a new, more sustainable system. We conclude with a discussion of the need and potential for transformation and an outlook towards possible first steps.

The analysis is based on several data sources: (1) multiple series of interviews addressing issues of adaptation to climate change, institutional change, water governance reforms, and international cooperation with donors, policy makers, and stakeholders in land and water management in Uzbekistan over the past 10 years, comprising about 80 interviews altogether, (2) a study of international donor involvement in the Aral Sea Basin (Schlüter 1999), and (3) results of ecological and socio- economic research and development projects in the Aral Sea Basin (Herrfahrdt 2004, Herrfahrdt et al. 2006, Schlüter et al. 2006, Schlüter et al. 2010a). The study of donor involvement provided an overview of the major national, regional, and international actors and their goals and activities to address the environmental crisis in the Aral Sea Basin. The research activities enabled a deepened insight into the Uzbek water and land reform processes, specific response measures such as the restoration of the Sudoche wetlands, as well as the restraining and enabling forces in the processes, such as the role of relevant institutions and actors.

\section{THE CONTEXT OF THE SES IN THE AMUDARYA RIVER BASIN}

We focus our resilience assessment on two organizational scales within Uzbekistan: the national and regional. The regional scale is defined as the Uzbek part of the delta region of the Amudarya River, which is the major Uzbek 
irrigation oasis in this river basin. It is also the region that borders the Aral Sea and is most affected by resource and environmental degradation. On the temporal scale we focus on the period after independence of the Central Asian republics from the Soviet Union in 1991, taking environmental and socio-economic developments prior to independence into account where they are necessary to understand recent trends.

In the semi-arid climate of the Turan lowlands all forms of agriculture require irrigation. The main source of irrigation water is surface water from the two main rivers in Central Asia, the Amudarya and the Syrdarya. Under Soviet rule beginning in the 1960 s, irrigated cotton production was massively extended to gain independence from cotton imports. In Uzbekistan, the area under cultivation increased from 0.42 million ha in 1913 to more than 4 million ha in 1990 (Spoor 1993, Herman 1999, World Bank 2000). In recent years it remains relatively stable at about 4.2 million ha (GEF 2002, FAO 2009). Low standards of water management, poor-quality and deteriorating infrastructure, and the frequent lack of drainage facilities led to inefficiencies that caused a number of environmental problems, such as soil salinization and waterlogging. Moreover, changes in river flow and expansion of agricultural land as well as massive water overuse have severely impacted the ecological subsystem, i.e., the seminatural ecosystems and the water and land resources in the delta area. This has resulted in the well-known disappearance of the Aral Sea, the loss of biodiversity and valuable ecosystem services such as fish and reed provision, pasture or protection from salt and dust storms, and loss of livelihood for the local population.

After the breakup of the Soviet Union an authoritarian political regime emerged with a very strong executive (March 2003, Schoeller-Schletter 2007). The civil society is weak (Stevens 2007) and in recent years has increasingly been constrained in its activities or even expelled from the country (ICG 2006). The Uzbek national budget and economy at large still depend heavily on irrigated agriculture, although the share of agriculture in the GDP has decreased from $30 \%$ in 2000 to $21 \%$ in 2007 (UNDP $2009 a$ ). Cotton production and export in particular serve as a source of foreign exchange, revenue and, with $60 \%$ of the population living in rural areas, needed employment. According to official data, which should be read with caution, the economy is steadily growing at rates between 3.8\% (2000) and
9.5\% (2008) per year (UNDP 2009b). However, growth does not appear to be trickling down to the poor. Estimates by the World Bank show that about $27.5 \%$ of the Uzbek population lives below the poverty line (World Bank 2003b). Apart from economic factors such as low prices for agricultural products and delayed payment of salaries, decreasing soil productivity, increasing soil salinity, and water-logging are identified as the main reasons for growing poverty in the rural areas (Herrfahrdt 2004). Additionally, health issues are becoming more severe, particularly in the environmentally degraded areas where good quality drinking water is often lacking (WHO 2006). Overall, environmental degradation has significantly impaired the living conditions and health situation of those living in the most affected areas making them more vulnerable to ecological, economic, and social stresses, as apparent, for example, during the drought in 2000/2001.

\section{DYNAMICS AND DRIVERS OF PAST AND PRESENT RESILIENCE}

\section{Past losses of resilience}

We analyze institutional responses and socialecological feedbacks determining the coevolution of the social and ecological systems during Soviet times and their impact on the resilience of the SES. Figure 2 exemplifies the underlying dynamics of slow environmental change that have caused the significant loss of ecological and social-ecological resilience observed today.

The low standards of water management practiced over the past 50 years, i.e., massive overuse of water in agriculture and improper drainage, caused waterlogging, soil salinization, and desertification of the deltaic wetlands and the Aral Sea and loss of livelihoods of the local population. This reduced the productivity of the agricultural sector, as seen in the outer red arrows of Figure 2. To mitigate the decline in agricultural production, the social system responded with further development of virgin lands ("irrigated area" in Figure 2) and technical measures such as establishment of a drainage system ("drainage construction") and leaching of the soils prior to irrigation ("leaching measures"). However, these responses further increased water use in agriculture which aggravated the environmental degradation. Leaching, for example, requires large amounts of water to maintain low salinity in the root 
Fig. 2. Major interactions and feedbacks between the ecological and social systems.

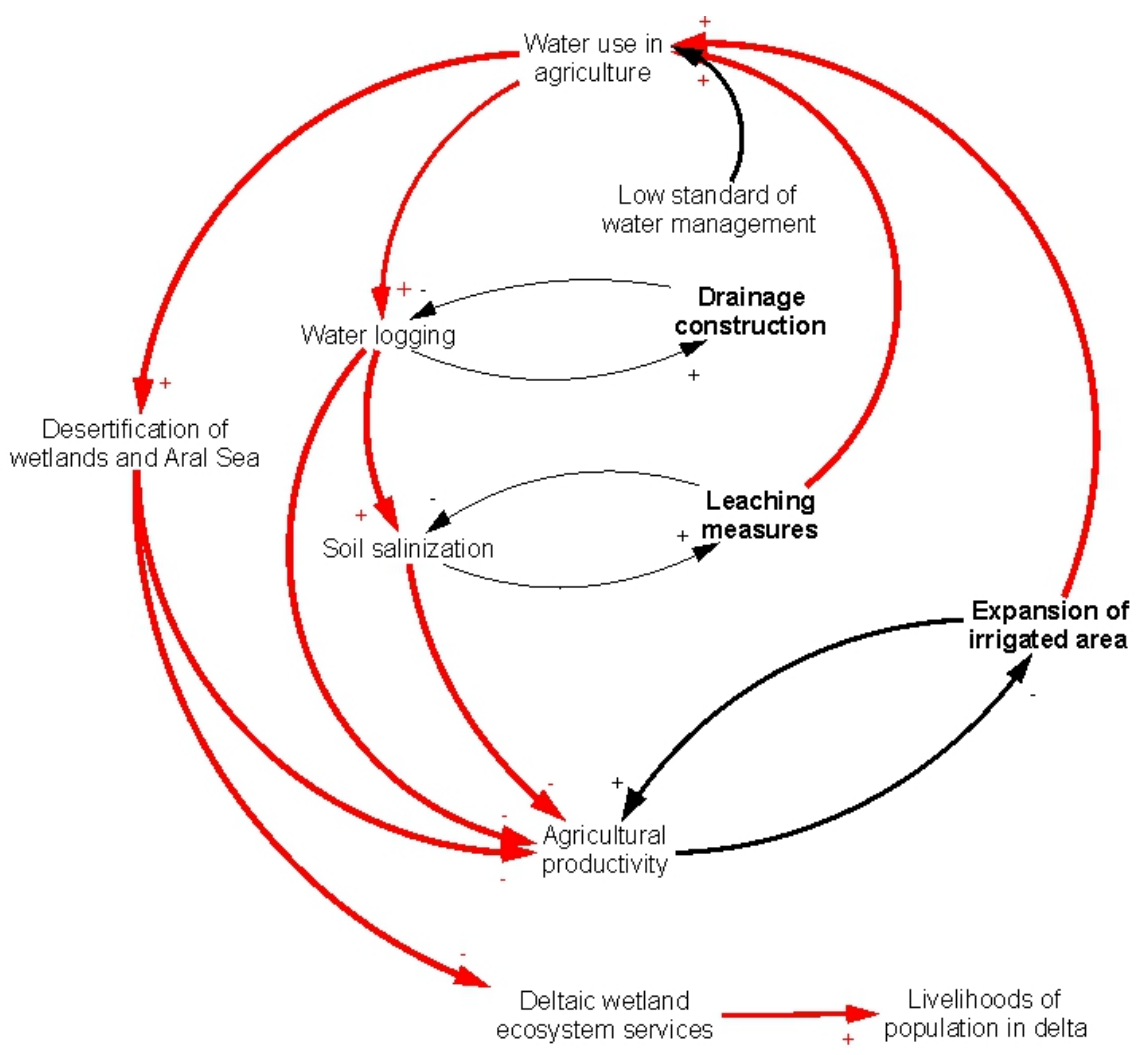

Note: The outer circles show longer-term impacts of increased water use in agriculture on ecosystems and agriculture and thus losses of resilience. The bold variables in the inner circles on the right hand side are management measures introduced as a response to environmental degradation and subsequent loss of agricultural productivity. The red arrows indicate the feedbacks created by the expansion of irrigated area and the low standard of water management. A minus sign indicates a negative feedback (e.g. a decrease in agricultural production leads to an increase in irrigated area), whereas a plus sign indicates a positive feedback (e.g. an increase in irrigated area leads to an increase in water use in agriculture).

zone. As a result, about $40 \%$ of the total amount of water diverted for irrigated agriculture disappears into the surface drainage system and is not used for plant growth (World Bank 2003a). Today's agricultural practices and lack of responsibility for the operation and maintenance of irrigation and drainage systems lead to further deterioration of irrigation infrastructure, lower efficiencies and yields, thus requiring yet more water to keep up with growing food demand (Abdullaev et al. 2009).

The ecological and economic consequences of resource overuse and ecosystem degradation are severe. In Karakalpakstan in 1999, $95 \%$ of the irrigated lands were salinized to some degree; in Khorezm province all irrigated areas suffer from salinization (GEF 2001). The trend is increasing rapidly, for example, the amount of saline areas in Uzbekistan increased by 26\% from 1990 to 1999. By $199980 \%$ of the irrigated area in the delta area (Khorezm and Karakalpakstan) had shallow water tables (Jakubov and Usmanov 2001). The total costs of salinization and water-logging for Uzbekistan, including the value of crop loss, costs for leaching, the operation and maintenance of drainage systems and the value of abandoned land, are estimated at 
US $\$ 529$ million per year or about $32 \%$ of the economic value of potential crop production (GEF 2002). The reduction of inflow to the Aral Sea caused its desiccation, along with the desertification of wetland and aquatic ecosystems in the Amudarya delta region. In the early 1960s, there were approximately 2,600 lakes in the Amudarya delta, but this had fallen to only 400 by 1985 (KreuzbergMukhina 2006). Many indigenous species have become extinct or are close to extinction and whole ecosystems, such as the characteristic Tugai forests that thrived along the river, have almost disappeared. Their area has decreased by $90 \%$ during the last century from the original 300,000 ha (Schlüter et al. 2006).

In general, the responses of the social system to environmental degradation, particularly expansion of irrigated land and leaching, were aimed at eliminating the consequences of resource deterioration in order to maintain agricultural productivity, but did not address its causes. The region entered into a positive feedback loop of environmental degradation which prompted further expansion of irrigated land and technical interventions to maintain production levels. This cycle was maintained by the demands of Moscow for cotton deliveries, focusing solely on yields and disregarding water use (Abdullaev et al. 2009). While in the short term the response of the social system ensured a stable flow of ecosystem services, such as cotton and economic rents, but creating vested interests and rent seeking, in the long run it caused further degradation and severely aggravated the situation. Planners realized the consequences of their activities; however, they often believed that in time technical measures, e.g. the diversion of Siberian rivers, would be available to mitigate the problems (interview no. 4, May 23 2006). The region still remains in this vicious cycle today.

This slowly progressing process of environmental degradation steadily decreased the resilience of the overall SES. One of the first and most striking manifestations of decreased resilience was the collapse of the Aral Sea fisheries in 1982. This regime shift caused the formerly prosperous fishing and fish canning industry, which processed between 50,000 and 300,000 t fish per year, on the shore of the Aral Sea to break down. Despite this major shock to the SES the social system at the national scale was not able or willing to address the loss of economic activity and left the Aral Sea region with few economic prospects. The result was a breakdown of the local social and economic subsystems, which decreased the resilience of the larger SES, for example, through migration and large-scale health problems. Today's large-scale soil salinization and waterlogging constitute another regime shift in the agricultural sector which is, however, still disguised by mitigation measures such as leaching. It is difficult to determine whether a regime shift has already occurred because there are no reliable data on agricultural productivity due to lack of transparency and incentives to exaggerate yields. A more reliable indicator of reduced resilience of the SES today is the significant damage caused by the extreme drought that occurred in 2000 and 2001 in the lower reaches of the Amudarya. Those include, but are not limited to, food shortages, such as a reduction in grain production by $54 \%$ in Karakalpakstan (FAO 2000), and huge economic losses, such as a reduction in cotton production by $30-40 \%$ in Karakalpakstan (FAO 2000), as well as further loss of ecosystem services in the delta, for example, the production of fish and clean drinking water.

\section{Socio-economic reform process after the breakup of the Soviet Union}

Independence was a sudden and not necessarily desired event for the former Soviet Union riverine countries of the Amudarya River, which happened without much contribution of their own. The reforms in Uzbekistan following independence were a reaction to the new political situation and a half-hearted attempt at a transition towards a new economy, which is not very clearly defined (Pomfret 2000). Uzbekistan was among the "slow reformers" from the onset, but during the first years after independence the government was committed to liberalize its economy; price controls were reduced, foreign trade liberalized, and exchange restrictions lifted (Pomfret 2000:7). This policy changed, however, in 1996 with the emergence of a balance of payments crisis (Anderson and Pomfret 2003). Increasing consumer goods imports, growing inflation, increasing foreign debt, and a poor cotton harvest, combined with falling world market prices for cotton, put the economy under considerable pressure. Following this shock, the government adjusted its reform course and strove for a restrictive and largely state-controlled economy by introducing multiple exchange rates, exchange controls, and import restrictions (Pomfret 2000, Wagstyl 2003, ICG 2004). Even though these measures were partly 
lifted in recent years, a state-centered approach persists. In the context of agriculture this approach has been termed "re-regulation" (Veldwisch and Spoor 2008:425).

We turn to highlighting major events of the agricultural and water sector reform processes that were initiated in conjunction with the economic transition (Figure 3).

\section{Land reforms}

The process of agricultural reform in Uzbekistan can be divided into three phases (Hofman 2007). The first phase (1991-1997) was dominated by the dismantling of state farms and saw the continuation of the state order system, at least for cotton and wheat, which had been in place since the 1920s when the Soviet administration transformed traditional water management and agricultural production into a government-regulated system with centrally controlled production targets (O'Hara 2000). The state order system has been transferred from Soviet times to ensure government control over production and a constant stream of revenues from agriculture. This path dependency was created by the need to balance the lack of inflow of financial resources from Moscow. Through the state order system of buying cotton and wheat for low prices from farmers and exporting it for much higher world market prices the government was able to compensate for the loss of budget support from Moscow following independence, which in 1990 amounted to about $20 \%$ of the budget (Herrfahrdt 2004). While in the 1990s the net outflow of resources from agriculture was estimated at about US \$1 billion, it ranged between US\$ 150 and US\$ 285 million between 2000 and 2003 (Veldwisch and Spoor 2008). Cotton exports accounted for about half of the hard currency earnings (ICG 2003). This dependence of the Uzbek government and economy on transfers from agriculture impedes substantial change or at least makes any reform that alters this arrangement highly unattractive. In addition to these disincentives, state officials profit from access to cotton revenues, which created vested interests in favor of the perpetuation of the state order system (Weinthal 2002, ICG 2003).

Even though state procurement quotas have been lowered from $100 \%$ in 1991 to $50 \%$ in 2002 for cotton and from $95 \%$ in 1991 to $30 \%$ in 2002 for wheat, this reduction has remained a change on paper, since at the same time the required output for cotton per hectare has been significantly increased by the government, and alternative markets are not accessible for farmers (Weinthal 2002, Spoor 2004, Veldwisch and Spoor 2008). Thus farmers still have to hand over the largest part of their production to the state at minimum state procurement prices, an arrangement which provides little incentive to farmers for increasing productivity. In fact it even negatively affects water management and use: Low state procurement prices render many farms economically almost unviable and prevent farmers from paying Water User Association (WUA) fees. This impedes WUAs from fulfilling their task of efficiently operating and maintaining the irrigation infrastructure. The consequences are overuse and high water losses (Abdullaev et al. 2009).

After independence, state regulation of wheat became an important instrument for increasing wheat production, achieving food self-sufficiency, and decreasing the reliance on expensive wheat imports. During this phase additional small plots were distributed to households for subsistence agriculture to serve as a buffer against poverty and social tensions (Veldwisch and Spoor 2008, Abdullaev et al. 2009). The first phase of reforms, however, proved to be inappropriate for solving mounting problems of environmental degradation, low productivity of the agricultural sector, and poverty due to a piecemeal approach and the disregard for social and environmental issues (Hofman 2007). Moreover, it resulted mainly in renaming old institutions instead of changing them (Weinthal 2002).

The second phase of reforms began with the adoption of the new land code in 1998 and, in an effort to increase productivity, new legislation on the organizational forms of agricultural entities (shirkats, which were agricultural cooperatives, private farms, and dekhkan/peasant farms). Shirkats were envisaged to become the most efficient organizations in the agricultural sector, which soon turned out to be unrealistic due to lack of incentives and an institutional environment that was still dominated by Soviet rules. The new land code did not alter property rights for land; all land still belongs to the state, and land ownership is possible only in the form of leasehold (Republic of Uzbekistan 1998). In addition, land was not so much distributed on a competitive basis, as was foreseen in the law, but the main drivers were rather formal and informal networks with local elites (Wegerich 
Fig. 3. Timeline of major events in the SES in the Uzbek part of the Amudarya River Basin

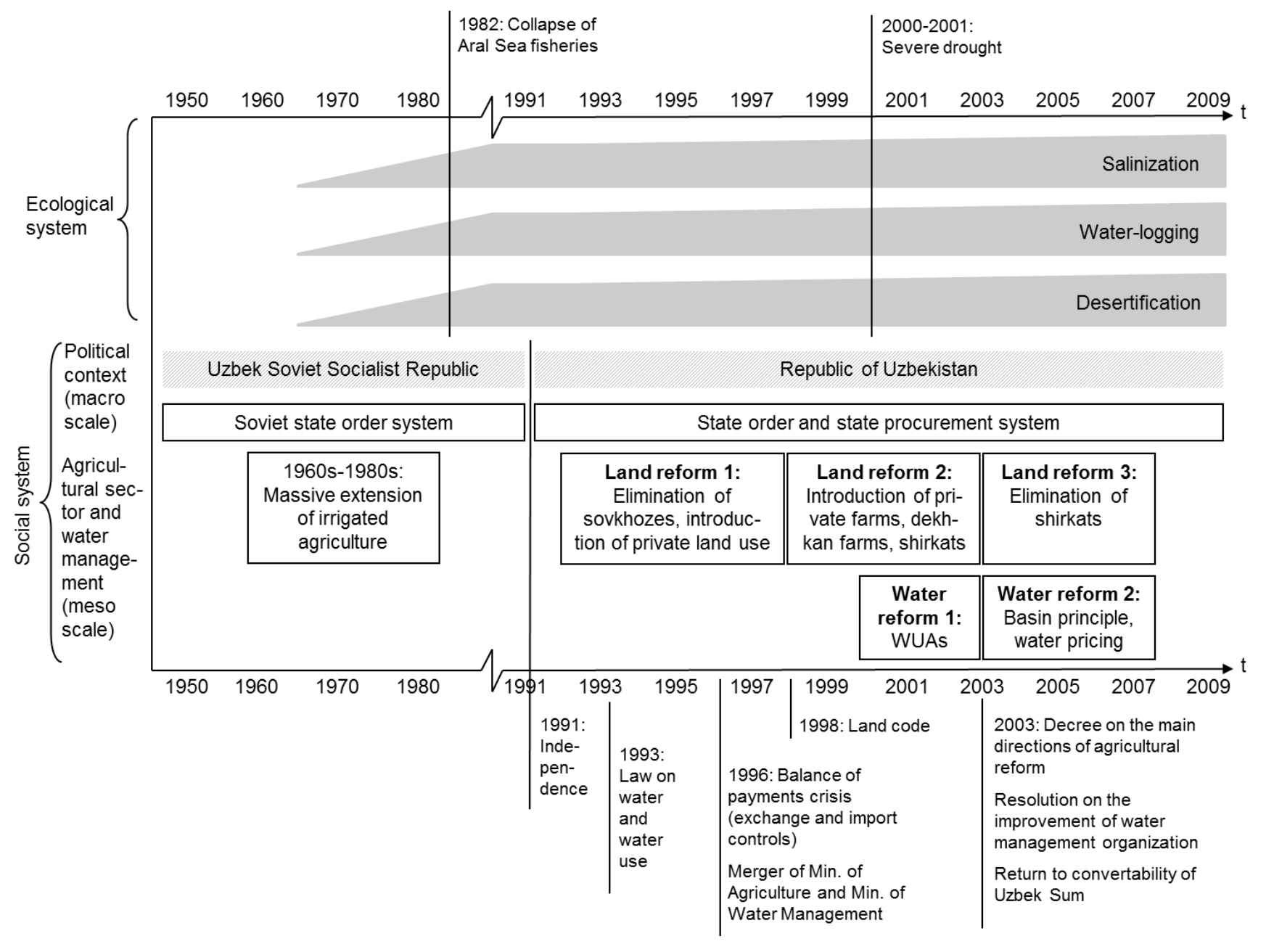

2002, Trevisani 2007). Generally, "institutionalized Soviet and pre-Soviet patterns of behavior still shape actors' responses to new challenges" (Sehring 2009:61).

During the third phase of land reform beginning in 2003 and in light of the poor performance of the shirkats, private farms were envisaged to become the principal model for agricultural production. The remaining shirkats were dismantled (interview no. 89, May 14 2007). Even though the state had now handed over most of the formerly state-owned agricultural farms to private owners, it nevertheless retained strong control over land and agricultural production through the system of state order and land property rights. The system thus provides little room for farmers to experiment with new cropping patterns and no incentives to increase cotton yields (Gunchinmaa and Yakubov 2010). The main aim of the reform process was to assure stability and continuous production of cotton as a strategic cash crop instead of a transformation of production patterns to more suitable ones (Veldwisch and Spoor 2008). As a consequence, land reforms were not suitable for increasing the resilience of the social system, e.g., through improving security of land rights or increasing efficient land use. Nor did they maintain or increase the resilience of the ecological system. 


\section{Water sector reforms}

Water management has been subordinated to the needs of agriculture and especially cotton production since Soviet times (Yalcin and Mollinga 2006). Consequently, water sector reforms lagged behind the land reform process. Through most of the 1990s, water management remained unchanged. The 1993 law on water and water use was mainly modeled on previous Soviet water management institutions. Water for irrigation remained free of charge, except for a negligible water tax, and water resources remained state property (Republic of Uzbekistan 1993). Significant institutional change occurred in 1996, however, when the Ministries of Agriculture and Water Resources were merged to become the Ministry of Agriculture and Water Resources (MAWR). The need for a centralization of agriculture and water issues in one organization and the continuing quarrels between the two independent ministries over water allocation were among the main reasons for the merger (Yalcin and Mollinga 2006, interview no. 66, April 30 2007). Reforms in the water sector were only slowly introduced from 2000 onward as a response to changes in the agricultural sector that made the Soviet water management administration unsuitable for serving thousands of newly established small farming entities and thus water users (Yalcin and Mollinga 2007). The result was the introduction of Water User Associations as the main water management organization at the local level.

The introduction of WUAs and the country-wide implementation of these new organizations were facilitated by several incidents. First, following the emergence of thousands of new farm entities with differential water needs a new level of water administration had to be introduced to relieve the district water management departments of the task of calculating water needs and allocating water to thousands of new water users. At the same time secondary and tertiary canals were neglected by the newly established farm entities and significantly deteriorated (Hamidov 2007). Second, several donors such as the World Bank, the Asian Development Bank and USAID were lobbying for a decentralization of water management and WUAs in particular and offered to provide financial support for their introduction. Third, apart from external pressure there was support for the concept from within the Ministry of Agriculture and Water Resources (MAWR); a MAWR official was convinced of the concept and used his position, contacts and family ties to lobby for the introduction of WUAs (Yalcin and Mollinga 2007). These circumstances and the strong dominance of the state in the process supported the relatively quick and country-wide implementation of WUAs, at least on paper. In practice most WUAs in Central Asia have become part of the existing patronage systems (Sehring 2009). Despite the fact that there is still huge room for improvement concerning the functioning of the WUAs and their role as independent actors within the water governance framework, farmers, notwithstanding their first reservations towards these new state-induced organizations, recently began to acknowledge the WUAs' role as a provider of water and training (interviews no. 1, May 19 2006, and no. 57, April 20 2007).

The reforms in the water sector gained new momentum and thus entered the second phase with the presidential decree on the main directions of agricultural reform in 2003, which stipulated that water management be organized according to the basin principle and which foresaw the introduction of market principles for water use (Republic of Uzbekistan 2003a, Republic of Uzbekistan 2003b). In the following period the province water management organizations were replaced by Basin Irrigation System Management units. They were established along hydrological boundaries, i.e., along river basins and canals instead of administrative boundaries of the provinces. Theoretically, the basin principle of water management is expected to improve water management through its focus on hydrographic instead of administrative boundaries and a reduction of administrative overload. This should lead to more transparency and increased capacity to detect and react to problems in resource availability or allocation. The introduction of this new institution in Uzbekistan was initiated by the water department within the MAWR, which, after the merger of the agricultural and the water ministries, has been struggling for independence from the agricultural sector, particularly regarding the disposition of the considerable budget for operation and maintenance of irrigation infrastructure (interview no. 56, April 16 2007, and no. 58, April 24 2007). With a hydrography-oriented management the water department's intention was to reduce the power of the agricultural department over the water department's budget and of the local governors (khokim) over water allocation. The khokim, however, are held responsible for fulfilling the state 
quotas for cotton and wheat in their districts. They thus have a strong interest in water management issues since they risk losing their jobs if quotas are not met (IWPR 2007). Accordingly, the khokim use their influence and power for intervention in water allocation, thus adding uncertainty and reducing the transparency of the water management system (Veldwisch 2008, interview no. 76, May 4 2007). One of the main goals of the institutional change in water allocation planning was thus not reached because of constraints of the larger institutional settings. Due to the lack of ownership for the topic the reform resulted in a mere renaming of water management organizations. It is important to note that since this second phase, water sector reforms have only been introduced by way of presidential decrees instead of laws that need the approval of parliament (interview no. 58, April 24 2007). This tendency towards governing by decrees can also be observed for agricultural reforms since 2003.

\section{INSTITUTIONAL RESPONSES TO ENVIRONMENTAL DEGRADATION AND RECENT SHOCKS}

While the reforms in land and water management slowly adapted the social system to the new political and socio-economic situation, they were not aimed at nor suited to address the growing deterioration of land and water resources and loss of valuable ecosystem services such as fish and reed production and protection from dust storms provided by the semi-natural ecosystems in the river basin. Institutional changes in the water sector were motivated by external events or changes in the social system itself rather than by the recognition of the need to address the deterioration and overuse of the resource base. Those external events or changes include the availability of donor support, the dismantling of the large farms in favor of many small ones, or power struggles in the Ministry of Agriculture and Water Resources. As during Soviet times, problems caused by resource degradation and increasing man-made water shortage were mainly addressed by technical measures aimed at maintaining current agricultural productivity. The underlying cycle of overuse and degradation of resources as previously described was neither addressed nor broken.

One of the few examples in which there is a direct response of the institutional sphere to ecological dynamics is in the case of extreme events such as droughts and floods (Schlüter et al. 2010b). These trigger an immediate response of the social system in the form of emergency measures, such as a ban on rice planting and a reduction of water limits for all regions, as was the case in 2007, or the establishment of an emergency council for transboundary cooperation in flood mitigation. Such emergency response measures that are reactive rather than proactive have been common for water or environmental management elsewhere (Wilhite 2005, Reagan 2006). However, once the extreme situation has passed, management returns to the old practices. Thus there are ad hoc reactions to immediate threats but no long-term government strategy to deal with the high variability in water flows and the growing water scarcity, such as reuse of drainage waters, diversification of agricultural production, change to less water-intensive crops, or diversification of water use (Krysanova et al. 2010). Moreover, informal institutions such as patronage and corruption severely limit implementation of the measures on the ground; according to the Corruption Perception Index Uzbekistan is among the ten most corrupt countries in the world (Transparency International 2009). The system thus remains vulnerable to future, probably increasing, disturbances in the form of droughts or flooding, particularly when they occur in combination with slow drivers such as loss of ecosystem services.

Another measure that might be interpreted as a response to the deteriorating ecological situation was the wetland restoration in the western delta region carried out within the framework of a large transboundary project funded by the World Bank. An example of measures that were at least partially initiated to mitigate the severe changes in the ecological system was the construction of polders in two bays of the former Aral Sea (Muynak bay and Sarbas) in 1994. While they were mainly planned for storage of excess water in high water years they also created new water bodies for fisheries which had been the main income source for the local population in the northern delta region (Autonomous Republic of Karakalpakstan). However, the productivity of those lakes is a function of water inflow, which remains highly unstable. Another attempt at wetland restoration was carried out under the umbrella of a large project of the World Bank. Here, the technical infrastructure and allocation rules for the mixture of drainage and freshwater inflow were installed to maintain water levels and an acceptable level of salinity in an important wetland, a potential Ramsar 
site, in the western part of the delta (Sudoche wetland). However, the institutional arrangements to secure the necessary freshwater inflow to those lakes and a sustainable exploitation of the biological resources of the wetland were only insufficiently developed. Thus, while the project was a success in reestablishing the wetland and providing the local population with new livelihood options its sustainability in the long run, especially since the number and severity of drought years might increase, is not guaranteed. The successful restoration of the wetland motivated the Uzbek government to further develop wetland restoration schemes for the delta to increase water storage capacity and, as a side effect, improve local livelihoods through the provision of wetland ecosystem services. But again, the lack of sufficient institutional arrangements that regulate the exploitation of the biological resources and the fact that their water requirements are not considered in water allocation limit the success of those measures. Wetland restoration thus fell short in increasing resilience of the regional SES because it focused solely on technical measures to improve the ecological conditions without developing institutions that regulate water supply and facilitate the sustainable use of the wetlands. Nevertheless the restoration measures and ecosystem recovery after the severe drought in 2000/2001 have revealed a high restoration potential of the deltaic wetlands and significant benefits to the local population (Ilya Joldasova, personal communication, Maja Schlüter, personal observation).

\section{DISCUSSION}

Despite massive ecological and socio-political pressures in the Amudarya River Basin, the water sector did not undergo institutional changes that would ensure the long-term sustainability of the SES. Our analysis identified a mismatch of the functioning of the resources and management regime as well as between different levels of the social regime. The reform process in the water sectors is mainly driven by the need to adapt to changes in the agricultural sector as well as power struggles and interests of individual leaders. As a result, resource overuse and ecological degradation in the river basin, at least in the Uzbek part of it, continue much as it did before the breakup of the Soviet Union. Small-scale institutional changes have been directed toward maintaining agricultural productivity in the short term and coping with the external and internal forces of the political and social system. The resulting cycle of declining agricultural productivity, leading to actions to mitigate the decline, leading to further environmental degradation and productivity decline, is well known in many other settings (Perrings 1989, Allison and Hobbs 2004, Anderies et al. 2006). With the collapse of the Aral Sea fisheries and the basin-wide large-scale soil salinization, the SES in the Amudarya River Basin has shifted to a new, less desirable regime. However, the high resilience of the social system, which is caused by strong feedbacks and path dependence, is keeping it in its current undesirable state and further degrades its long-term resilience. The window of opportunity for significant changes of the larger scale institutional setting that might have been open after the breakup of the Soviet Union was or could not be used to achieve a transformation to more sustainable resource use.

\section{Path dependence, lock-in, and decrease of overall resilience}

As a consequence of historic developments in the agricultural sector and the strong feedbacks they created, the SES in the Amudarya River Basin is locked into a state that is still determined by the legacies of the Soviet Union to a large extent. Those include the hierarchical water management culture and a fragmentation of responsibilities that still prevail today (Sehring 2009). The decision to stick to the state order system and the rents it creates for the political elite enforced this strong path dependence. The importance of cotton for the state budget, employment in rural areas, and the stability of the country in general precluded serious reforms in the agricultural sector. Without reforms in the agricultural sector, there is little option for reforms in the water sector. Moreover, cotton production is important as a system of social, economic, and political control (Weinthal 2001, ICG 2005). A transformation of the agricultural sector would have threatened the very foundation of social control, which is built on reciprocal relationships between the central leadership, the regional leadership, and the heads of farms (Weinthal 2001). Regionalism and patronage networks from pre-Soviet and Soviet times still prevail today (Collins 2002, Starr 2006). Through them vested interests of powerful players can influence political decisions or at least their implementation on the ground, as the case of land distribution has shown. There are few incentives for 
powerful actors to engage in serious structural economic reform, which could threaten their economic and political access and power (Jones Luong 2002, ICG 2005). Even though a multitude of legal reforms and regulations have been enacted in Uzbekistan since independence, in many cases changes have been rather insignificant, and largely remained a "patchwork process" (SchoellerSchletter 2008:21). Small adjustments have been carried out in cases in which underlying power structures and vested interests were either not touched or could be supported through the changes. The lack of real structural changes in land and water use on the national scale reduces the long-term resilience of the SES in the river basin. Such small changes at best increase the short-term resilience of the social system by ensuring continued cotton yields. In the long run, however, they increase the vulnerability of the system to external and internal shocks, for example, by leading to increased poverty and the decreasing health status of the rural population. As a result there has been increasing social unrest, especially in 2004 and 2005 (ICG 2006).

\section{Constraints to adaptability in the water sector by higher scale institutional setting}

Many of the new institutions introduced through the land and water sector reform process are ineffective at changing water management practices because they do not take the larger scale institutional or political settings, such as the primacy of agriculture and especially the impact of the state order on water management, into account (Walker et al. 2009). Moreover, structural weaknesses of the formal legal system which provide the executive with authoritarian powers act as a strong barrier for innovation and structural change (SchoellerSchletter 2008). For example, a land reform that "privatizes" land has been introduced, but use rights are not secure (Veldwisch and Spoor 2008). As a result, there are few incentives for investments in amelioration and irrigation infrastructure, and thus the intended benefits of the reform are not realized. Another example is the WUAs, which cannot function as long as the influence of the local governors on crop and water allocation is not reduced. Institutions such as water markets, water service fees, and land markets, which are needed to make the already implemented institutions such as private farms or WUAs work properly, are lacking. The very strong and dominant role of the state is also visible in the fact that in recent years land and water reforms are often enacted as decrees instead of laws. This demonstrates the urgency and relevance of the issue for the president but also a loss of democratic principles in that the parliament is bypassed (Schoeller-Schletter 2007).

\section{Need for transformation}

Policy measures that have been proposed by the international community to increase the adaptability of the system include the development of institutions that regulate resource use and provide incentives for their sustainable use, such as water pricing and water markets. Implementation on the ground, however, is rudimentary for many of the reasons discussed, and a change in the perception of water as a limited resource has so far only taken place to a limited degree; in high water years, people don't see a need to save water. Many policy makers in the region see an increase in water use efficiency through technical measures as a panacea for all problems. Given the huge losses of over $70 \%$ in the current irrigation system (GEF 2002) caused by operational deficits and seepage, a significant increase in efficiency is certainly possible. It would allow the continuation of current water use activities for some time and free resources for further expansion of irrigated agriculture and the delivery of environmental flows to the deltaic wetlands. However, it cannot be achieved solely by technical means. To be effective, the measures have to go beyond incremental institutional changes to the current system to include, e.g., a careful abandonment of the state order system, the introduction of water service fees, secure land rights, land markets, and the implementation of environmental flows to the deltaic wetlands. Given these adjusted boundary conditions, higher incomes, water service fees, and secure land entitlements could provide the needed incentives and security for farmers to invest in irrigation infrastructure and increase water use efficiency. Moreover, there is a need for diversification of water use by giving other water users rights to the resources and reducing the vulnerability of both the social and ecological systems, e.g., through restoring ecological processes, providing health services, and alternative income opportunities in rural areas. However, adaptation in agricultural and water governance alone, even if truly implemented, does not provide a long-term solution to the region's unsustainable resource use because of the ongoing 
environmental degradation, the growing population, and lack of virgin lands. Resilience and transformability of the larger-scale SES (political, economic and institutional settings) is needed to enable the smaller scales (regional and local water management) to adapt and change.

\section{Potential for transformation}

A transformation goes further than the measures suggested in that it questions and changes current patterns of economic activity and resource use and leads to a less water-intensive mode of production. This could, for example, include abandoning low productivity soils, switching to other less waterintensive crops, further developing tourism, and exploring the options in other sectors. However, with the current power constellations and rents from agricultural production for the local and regional elites, a transformation of the larger scale SES initiated through the prevailing top-down governance system seems unlikely in the near future. In addition, many of the key elements that have been identified as underlying and promoting successful transformations in other cases are lacking in the Uzbek SES. Those include the acceptance of change and the need for it, the existence of trust and leadership, a cutback of incentives that maintain the current regime, the political capacity to implement structural change, and strategic investments in social and human capital, infrastructure and technology (Gunderson et al. 2006, Olsson et al. 2006, Walker et al. 2009). Moreover, there is no stakeholder involvement that could promote a negotiation process resulting in a reframing of perspectives, and social entrepreneurship and institutional support are missing, all of which are factors relevant for social transformations (Biggs et al. 2010). While there has been a cascade of shocks and regime shifts in subsystems (Kinzig et al. 2006), such as the collapse of the Aral Sea fisheries that caused a regime shift of the SES in the delta region, the environmental and socio-political crises were in and of themselves not sufficient to trigger structural changes (Biggs et al. 2010). The case study has also revealed the presence of strong social networks; however, contrary to other examples they do not foster learning, counter maladaptation or create flexible institutional arrangements as suggested by Gunderson et al. (2006). Learning as another essential ingredient of transformative change is prevented by the feedback loops created by the vested interests and the prevailing centralized governance regime (Huntjens et al. in press, Schlüter et al. 2010b).

However, there are also a few promising signs, albeit still very small and modest. One first move that could potentially foster a transformation are the 2007 and 2008 decrees on measures to optimize soil amelioration and the cultivated area and increase the production of food crops (Republic of Uzbekistan 2007 and 2008). They make reference to the increasing share of saline soils as well as water scarcity of recent years and as a consequence foresee a reduction of cotton area by $5 \%$ in favor of food crops. Change can also originate from below and cascade up the social hierarchy. With farmers beginning to trust WUAs and acknowledging their usefulness, the WUAs, for example, might turn out to be a nucleus of adaptive change in Uzbek water management. There are a few first indicators that support such a notion: the land reforms have induced shifts in the patterns of political dynamics in rural Uzbekistan (Trevisani 2007) and in power relations in favor of local actors who gain bargaining power and implement changes (Wegerich 2005); an increasing number of farmers are beginning to resist the state order system (Wall 2006) and they are becoming increasingly aware of their rights and begin to assert them (interview no. 8, April 282007 ). During stakeholder workshops organized within the framework of the EU research project NeWater (Hirsch et al. 2010), local communities have called for measures that improve the strength of formal institutions (e.g., through enforcement), build human capital, and improve planning and adaptation procedures as key interventions toward more sustainable water resource management (Schluiter et al. 2010b). The potential for initiating the transformation that these bottom-up processes entail can however only be realized if the system manages to self-organize around them despite the resistance from the higher level governance system (Sendzimir et al. 2008). Given the very hierarchical and rigid system and the resistance to change from the elites and higher levels of water management it remains unclear whether transformative change will materialize in a bottom-up approach (see Bohensky 2008 for a discussion of bottom-up processes in the South African water management context). 


\section{CONCLUSION}

The case of resilience and transformability in the lower Amudarya river basin is an example of a SES in which there is very high current resilience of the social system that is acting against a needed transformation. The gradual and rather superficial reforms of water management have not promoted resilience of the social-ecological system since they did not lead to real functional changes but merely entailed changes on paper with little measurable effects on water management practices and water use. The case illustrates how efforts to enhance adaptability of subsystems by those who gain from their functioning have led to loss of resilience of the overall SES (Walker et al. 2006). Even though the SES has been exposed to severe shocks in the social and ecological systems that can be termed a major crisis, it was not able to transform or even adapt its resource use patterns toward a more sustainable mode. Soviet legacies, path dependence, strong central control, and the power of informal institutions and vested interests of powerful actors have proven strong enough to withstand these shocks and the shifts they entailed. They have facilitated the maintenance of a maladaptive social system that persists at the expense of the resilience of the ecological and the overall social-ecological system. Similar patterns have been observed in other post-Soviet or post-socialist Eastern European countries, such as Hungary (Sendzimir et al. 2008) or Bulgaria (Theesfeld 2004). A transformation at the larger scale, e.g., the scale of the national economy and governance system, is needed to allow for adaptation at the lower scales, e.g., in the water sector. For the Uzbek case, it is still too early to judge whether the newly introduced decentralized structures such as the WUAs will manage to create alternative feedback loops that can eventually shift the system into a new state and thus increase resilience.

One might speculate that once the economic losses from mismanagement and overuse of natural resources are great enough to threaten state budgets and existing rents, the political willingness to engage in comprehensive reforms might increase. With a view to the still relatively low levels of discontent among the population, however, the length of time it will take until this point is reached and whether the system will still have enough capacity and time to reorganize and prevent a collapse at that point are questionable. We see the following as priorities for moving along a path of socially acceptable transformation along the lines of the needed larger scale institutional changes: a careful abandonment of the state order system by simultaneously providing access to markets for local farmers, followed by the introduction of incentives for sustainable water use, changes in cropping patterns and a reduction of the dominance of the agricultural sector, as well as rehabilitation of the deltaic ecosystems. The region has sufficient water resources to provide adequate nutrition for a population twice the size of the present one (UNESCO 2000). While it is impossible to restore the southern part of the Aral Sea (the northern part, which is fed by the Syrdarya river, is currently rehabilitating), the ecosystems in the Amudarya delta have shown a remarkably high restoration potential despite the existing extensive ecological damage. By incorporating the needs of the ecological system into water management, productivity, sustainability, and thus the resilience of the SES in the Amudarya River Basin can be greatly enhanced.

Reflecting on these results, our resilience assessment has shown the importance of taking different scales and cross-scale interactions into account when assessing resilience and developing measures for more sustainable resource use. Furthermore, it has revealed the relevance of the political economy of resource use and its role as a potential barrier to transformation. Issues such as power relations, agency, the role of individual actors, and rent-seeking, which have a long research tradition in other social science fields, need to receive more attention in the resilience and transformation literature in general and in the analysis of SESs in particular (Smith and Stirling 2010). The role of informal institutions, such as vested interests, corruption, and patronage in impeding change, and the increase or decrease of resilience seem to be particularly crucial. The case of Uzbekistan further shows that some features such as social networks identified in other case studies as promoting resilience and transformation may also serve as barriers to transformation and decrease the resilience of a SES. Finally, the assessment demonstrates the importance of the ability to transform at higher levels, i.e., the national agricultural policies, as an enabling factor for transformability at lower levels, i.e., the water sector at local levels. 
Responses to this article can be read online at: http://www.ecologyandsociety.org/voll6/iss1/art32/ responses/

\section{Acknowledgments:}

The authors would like to thank Katrin Daedlow and two anonymous reviewers for valuable comments that helped to improve an earlier version of this manuscript. We are also very thankful to Anja Schoeller-Schletter for sharing her knowledge on the Uzbek legal system with us. The research was supported by the European Commission (Contract $N^{\circ} 511179$ - NEWATER). MS acknowledges the support of a Marie Curie International Fellowship within the 6th European Community Framework Programme as well as the project Besatzfisch funded by the German Ministry of Education and Research in the Program for Social-Ecological Research (grant 01UU0907).

\section{LITERATURE CITED}

Abdullaev, I., C. De Fraiture, M. Giordano, M. Yakubov, and A. Rasulov. 2009. Agricultural water use and trade in Uzbekistan: situation and potential impacts of market liberalization. International Journal of Water Resources Development 25:47-63.

Abel, N., D. H. M. Cumming, and J. M. Anderies. 2006. Collapse and reorganization in socialecological systems: questions, some ideas, and policy implications. Ecology and Society 11(1):17. [online] URL: http://www.ecologyandsociety.org/vol11/ iss1/art17/.

Allison, H. E., and R. J. Hobbs. 2004. Resilience, adaptive capacity, and the "lock-in trap" of the Western Australian agricultural region. Ecology and Society 9(1):3. [online] URL: http://www.ecolo gyandsociety.org/vol9/iss1/art3/.

Anderies, J. M., M. A. Janssen, and E. Ostrom. 2004. A framework to analyze the robustness of socialecological systems from an institutional perspective. Ecology and Society 9(1):18. [online] URL: http:// www.ecologyandsociety.org/vol9/iss1/art18/

Anderies, J. M., P. Ryan, and B. H. Walker. 2006. Loss of resilience, crisis, and institutional change: lessons from an intensive agricultural system in southeastern Australia. Ecosystems 9:865-878.

Anderson, K. H., and R. Pomfret. 2003. Consequences of creating a market economy: evidence from household surveys in Central Asia. Edward Elgar, Cheltenham, UK, Northampton, MA, USA.

Biggs, R., F. R. Westley, and S. R. Carpenter. 2010. Navigating the back loop: fostering social innovation and transformation in ecosystem management. Ecology and Society 15(2):9. [online] URL: http://www.ecologyandsociety.org/vol15/iss2/ $\underline{\operatorname{art9l}}$

Bohensky, E. L. 2008: Discovering resilient pathways for South African water management: two frameworks for a vision. Ecology and Society 13 (1):19. [online] URL: http://www.ecologyandsociety. org/vol13/iss1/art19/.

Chapin, F.S., III, M. Hoel, S. R. Carpenter, J. Lubchenko, B. Walker, T. V. Callaghan, C. Folke, S.A. Levin, K.G. Mäler, C. Nillson, S. Barrett, F. Berkes, A. S. Crépin, K. Danell, T. Rosswall, D. Starrett, A. Xepapadeas, and S.A. Zimov. 2006. Building resilience and adaptation to manage Arctic change. Ambio 35:198-202.

Collins, K. 2002. Clans, pacts, and politics in Central Asia. Journal of Democracy 13:138-152.

FAO (Food and Agriculture Organization of the United Nations). 2000. Global information and early warning system on food and agriculture: crop and food supply assessment mission to the Karakalpakstan and Khorezm regions of Uzbekistan. FAO, Rome, Italy. online [URL]: http://www.fao.o rg/docrep/004/x9188e/x9188e00.htm

FAO (Food and Agriculture Organization of the United Nations). 2009. AQUASTAT: FAO's information system on water and agriculture. [online] URL: http://www.fao.org/nr/water/aquastat/ dbase/index.stm.

Folke, C. 2006. Resilience: the emergence of a perspective for social-ecological systems analyses. Global Environmental Change 16(3):253-267

Folke, C., L. Pritchard Jr., F. Berkes, J. Colding, and $\mathrm{U}$. Svedin. 1998. The problem of fit between ecosystems and institutions. IHDP Working Paper 
No. 4121-41602. A report for the IHDP (International Human Dimensions Programme on Global Environmental Change). Bonn, Germany.

Folke, C., L. Pritchard, F. Berkes, J. Colding, and U. Svedin. 2007. The problem of fit between ecosystems and institutions: ten years later. Ecology and Society 12(1):30. [online] URL: http://www.ec ologyandsociety.org/vol12/iss1/art30.

GEF (Global Environment Facility). 2001. Water and environmental management project: Subcomponent A1, Uzbek national report. GEF Agency of the IFAS Aral Sea Basin Program, Tashkent, Uzbekistan.

GEF (Global Environment Facility). 2002. Water and environmental management project: Subcomponent A1, Regional report No. 2. GEF Agency of the IFAS Aral Sea Basin Program, Tashkent, Uzbekistan.

Gunchinmaa, T., and M. Yakubov. 2010. Institutions and transition: does a better institutional environment make water users associations more effective in Central Asia? Water Policy 12:165-185.

Gunderson, L. H, S. R. Carpenter, C. Folke, P. Olsson, and G. Peterson. 2006. Water RATs (resilience, adaptability, and transformability) in lake and wetland social-ecological systems. Ecology and Society 11(1):16. [online] URL: http:/ /www.ecologyandsociety.org/vol11/iss1/art16/

Hamidov, A. 2007. Water User Associations in Uzbekistan: review of conditions for sustainable development. Working Paper. World Bank Institute (WBI). Washington D.C., USA.

Herman, M. 1999. Sustainable agricultural reform the case of Uzbekistan. Pages 84-95 in UNDP Regional Bureau for Europe and the CIS, editor. Central Asia 2010: prospects for human development. Regional Bureau for Europe and the CIS, New York, USA.

Herrfahrdt, E. 2004. Landwirtschaftliche Transformation, Desertifikation und nachhaltige Ressourcennutzung: Fallbeispiel Usbekistan. Deutsches Institut für Entwicklungspolitik, Bonn, Germany.

Herrfahrdt, E., M. Kipping, T. Pickardt, M. Polak, C. Rohrer, and C. F. Wolff. 2006. Water governance in the Kyrgyz agricultural sector: on its way to integrated water resource management? Deutsches Institut für Entwicklungspolitik, Bonn, Germany.
Hirsch, D., G. Abrami, R. Giordano, S. Liersch, N. Matin, and M. Schlüter. 2010. Participatory research for adaptive water management in a transition country-a case study from Uzbekistan. Ecology and Society 15(3):23. [online] URL: http:/ /www.ecologyandsociety.org/vol15/iss3/art23/

Hofman, I. 2007. Agrarian Reform...the pathway to sustainability? The case of Urta, Yukori and Quyi Chirchik. Thesis. Wageningen University, Wageningen, The Netherlands.

Huntjens, P., C. Pahl-Wostl, B. Rihoux, M. Schlüter, Z. Flachner, S. Neto, R. Koskova, C. Dickens, and I. Nabide Kiti. In press. Adaptive water management and policy learning in a changing climate - a formal comparative analysis of eight water management regimes in Europe, Africa, and Asia. Environmental Policy and Governance.

ICG (International Crisis Group). 2003. Uzbekistan's reform program: illusion or reality? ICG, Osh, Kyrgyzstan; Brussels, Belgium. Osh, Kyrgyzstan; Brussels, Belgium. online [URL]: http://www.crisi sgroup.org/ /media/Files/asia/central-asia/ uzbekistan/046\%20-\%20Uzbekistans\%20Reform\% 20Program\%20-\%20Illusion\%20or\%20Reality.ashx

ICG (International Crisis Group). 2004. The failure of reform in Uzbekistan: ways forward for the international community. ICG, Osh, Kyrgyzstan; Brussels, Belgium. online [URL]: http://www.crisi sgroup.org/ /media/Files/asia/central-asia/ uzbekistan/076 failure of reform in uzbekistan.ashx

ICG (International Crisis Group). 2003. Uzbekistan's reform program: illusion or reality? ICG, Osh, Kyrgyzstan; Brussels, Belgium. Osh, Kyrgyzstan; Brussels, Belgium. online [URL]: http://www.crisi sgroup.org/ /media/Files/asia/central-asia/ uzbekistan/046\%20-\%20Uzbekistans\%20Reform \% 20Program\%20-\%20Illusion\%20or\%20Reality.ashx

ICG (International Crisis Group). 2006. Uzbekistan: in for the long haul. ICG, Bishkek, Kyrgyzstan; Brussels, Belgium. online [URL]: http://www.crisi sgroup.org/ /media/Files/asia/central-asia/uzbekistan/ b045 uzbekistan in for the long haul.ashx 
IWPR (Institute of War and Peace Reporting). 2007. Reporting Central Asia No.498, special report: reaping an unripe harvest in Uzbekistan. [online] URL: http://www.mail-archive.com/reporting cent ral asia english@iwpr.gn.apc.org/msg00051.html

Jakubov, K., and A. Usmanov. 2001. Report to identify and map main sources of salt generation. Regional working group. GEF Agency of the IFAS Aral Sea Basin Program, Tashkent, Uzbekistan.

Jones Luong, P. 2002. Political obstacles to economic reform in Uzbekistan, Kyrgyzstan, and Tajikistan: strategies to move ahead. World Bank Working Paper. World Bank, Washington, D.C., USA.

Kinzig, A. P., P. Ryan, M. Etienne, H. Allison, T. Elmqvist, and B.H. Walker. 2006. Resilience and regime shifts: assessing cascading effects. Ecology and Society 11(1):20. [online] URL: http://www.ec ologyandsociety.org/vol11/iss1/art20/

Kreuzberg-Mukhina, E. A. 2006. The Aral Sea basin: changes in migratory and breeding waterbird populations due to major human-induced changes to the region's hydrology. Pages 283-284 in G. C. Boere, C. A. Galbraith, and D. A. Stroud, editors. Waterbirds around the world. The Stationary Office, Edinburgh, UK.

Krysanova, V., C. Dickens, J. Timmerman, C. Varela-Ortega, M. Schlüter, K. Roest, P. Huntjens, F. Jaspers, H. Buiteveld, E. Moreno, J. de Pedraza Carrera, R. Slámová, M. Martinkova, I. Blanco, P. Esteve, K. Pringle, C. Pahl-Wostl, and P. Kabat. 2010. Cross-comparison of climate change adaptation strategies across large river basins in Europe, Africa and Asia. Water Resources Management. 24(14):4121-4160.

March, A. 2003. From Leninism to Karimovism: hegemony, ideology, and authoritarian legitimation. Post-Soviet Affairs 19:307-336.

O'Hara, S. L. 2000. Lessons from the past: water management in Central Asia. Water Policy 2:365384.

Olsson, P., L. H. Gunderson, S. R. Carpenter, P. Ryan, L. Lebel, C. Folke, and C. S. Holling. 2006. Shooting the rapids: navigating transitions to adaptive governance of social-ecological systems.
Ecology and Society 11(1):18. [online] URL: http:/ /www.ecologyandsociety.org/vol11/iss1/art18/

Perrings, C. 1989. An optimal path to extinction: poverty and resource degradation in the open agrarian economy. Journal of Development Economics 30:1-24.

Pomfret, R. 2000. The Uzbek model of economic development, 1991-9. Economics of Transition 8 (3).

Reagan, D. P. 2006. An ecological basis for integrated environmental management. Human and Ecological Risk Assessment 12:819-833.

Republic of Uzbekistan. 1993. Law on water and water use [title translated from the Russian language]. Uzbek Government, Tashkent, Uzbekistan.

Republic of Uzbekistan. 1998. Land Code of the Republic of Uzbekistan [title translated from the Russian language]. Uzbek Government, Tashkent, Uzbekistan.

Republic of Uzbekistan. 2003a. Decree on the major directions of reforms in the agricultural sector [title translated from the Russian language]. Uzbek Government, Tashkent, Uzbekistan.

Republic of Uzbekistan. 2003b. Resolution of the cabinet of ministers of the Republic of Uzbekistan July 21, 2003: The improvement of water management organization [title translated from the Russian language]. Uzbek Government, Tashkent, Uzbekistan.

Republic of Uzbekistan 2007. On measures to improve the system for the melioration of soils [title translated from the Russian language]. Uzbek Government, Tashkent, Uzbekistan.

Republic of Uzbekistan 2008. Decree on measures for optimizing cultivated areas and increasing food crop production [title translated from the Russian language]. Uzbek Government,Tashkent, Uzbekistan.

Schlüter, M. 1999. International cooperation in addressing the consequences of the Aral Sea crisis. Robert Bosch Foundation, Program for International Affairs, Tashkent, Uzbekistan.

Schlüter, M., D. Hirsch, D. Abdullaev, E. Herrfahrdt-Pähle, R. Giordano, M. Khamirzaeva, 
G. Khasankhanova, N. Kranz, S. Liersch, N. Matin, A. Salokhiddinov, A. Savitsky, C. Siderius, and R. Toryannikova. 2010a. The Amudarya case study. Pages 143-155 in J. Mysiak, H. J. Henriksen, C. Sullivan, J. Bromley, and C. Pahl-Wostl, editors. The adaptive water resource management handbook. Earthscan, London, UK.

Schlüter, M., D. Hirsch, and C. Pahl-Wostl. $2010 b$. Coping with change - responses of the Uzbek water management regime to socio-economic transition and global change. Environmental Science and Policy 13(7):620-636.

Schlüter, M., N. Rüger, A. Savitsky, N. Novikova, M. Matthies, and H. Lieth. 2006. An integrated simulation tool for ecological assessment of alternative water management strategies in a degraded river delta. Environmental Management 38:638-653.

Schoeller-Schletter, A. 2007. Structural deficits in legal design and excessive executive power in the context of transition in Uzbekistan. Pages 241-258 in P. Sartori, and T. Trevisani, editors. Patterns of transformation in and around Uzbekistan. Diabasis, Reggio Emilia, Italy.

Schoeller-Schletter, A. 2008. Organizing agricultural production: law and legal forms in transition. Pages 17-42 in P. Wehrheim, A. Schoeller-Schletter, and C. Martius, editors. Continuity and change: land and water use reforms in rural Uzbekistan, socioeconomic and legal analyses for the region Khorezm. Institut für Agrarentwicklung in Mittelund Osteuropa (IAMO), Halle, Germany.

Sehring, J. 2009. Path dependence and institutional bricolage in post-Soviet water governance. Water Alternatives 2:61-81.

Sendzimir, J., P. Magnuszewski, Z. Flachner, P. Balogh, G. Molnar, A. Sarvari, and Z. Nagy. 2008. Assessing the resilience of a river management regime: informal learning in a shadow network in the Tisza river basin. Ecology and Society 13(1):11 [online] URL: http://www.ecologyandsociety.org/vol13/ $\underline{\text { iss } 1 / \operatorname{art} 11 /}$

Siderius, C., and O. Schoumans. 2008. Baseline assessment Amudarya on water quality, quantity and ecosystems. Report of the NeWater projectNew Approaches to Adaptive Water Management Under Uncertainty, Deliverable D 2.3.1a.
Wageningen, The Netherlands. [online] URL: $\underline{\mathrm{a}} \mathrm{hr}$ ef="http://www.newater.uos.deintern/sendfile.php? $\underline{\mathrm{id}=466}$

Smith, A., and A. Stirling. 2010. The politics of social-ecological resilience and sustainable sociotechnical transitions. Ecology and Society 15(1):11. [online] URL: http://www.ecologyandsociety.org/vol15/iss 1/ $\underline{\operatorname{art11}}$

Spoor, M. 1993. Transition to market economies in former Soviet Central Asia: dependency, cotton and water. European Journal of Development Research 5:142-158.

Spoor, M. 2004. Usbekistan's agrarian transition.in Minisymposium agricultural transformation: lessons from five transition countries. Mansholt Graduate School of Social Sciences, Wageningen, The Netherlands.

Starr, S. F. S. 2006. Clans, authoritarian rulers, and parliaments in Central Asia. Central Asia-Caucasus Institute, Silk Road Studies Program, Washington, D.C., USA

Stevens, D., 2007. Political society and civil society in Uzbekistan- never the twain shall meet? Central Asian Survey 26(1):49-64.

Theesfeld, I. 2004. Constraints on collective action in a transitional economy: the case of Bulgaria's irrigation sector.World Development 32:251-271.

Transparency International. 2009. Corruption perception index 2009. [online] URL: http://www.t ransparency.org/policy research/surveys indices/cpi/2009/ cpi 2009 table

Trevisani, T. 2007. After the Kolkhoz: rural elites in competition. Central Asian Survey 26:85-104.

UNDP (United Nations Development Programme). 2009a. Uzbekistan in figures: Gross Domestic Product. [online] URL: http://data.statistics.uz/data finder $/ 3430$

UNDP (United Nations Development Programme). 2009b. Uzbekistan in figures: economy at a glance. [online] URL: http://data.statistics.uz/data finder/64/ \#2004

UNESCO (United Nations Educational, Scientific and Cultural Organisation). 2000. The water-related 
vision for the Aral Sea basin for the year 2025. UNESCO, Paris, France.

Veldwisch, G. J. 2008. Cotton, rice \& water - the transformation of agrarian relations, irrigation technology and water distribution in Khorezm, Uzbekistan. Dissertation. University of Bonn, Bonn, Germany.

Veldwisch, G. J., and M. Spoor. 2008. Contesting rural resources: emerging 'forms' of agrarian production in Uzbekistan. The Journal of Peasant Studies 35:424-451.

Wagstyl, S. 2003. Doubts over impact of Uzbeks' currency reform. Financial Times.

Walker, B. H., N. Abel, J. M. Anderies, and P. Ryan. 2009. Resilience, adaptability, and transformability in the Goulburn-Broken Catchment, Australia. Ecology and Society 14(1):12. [online] URL: http:/ /www.ecologyandsociety.org/vol4/iss 1/art12/

Walker, B., C. S. Holling, S. R. Carpenter, and A. Kinzig. 2004. Resilience, adaptability and transformability in social-ecological systems. Ecology and Society 9(2):5. [online] URL: http://w ww.ecologyandsociety.org/vol9/iss2/art5/

Wall, C. 2006. Peasant resistance in Khorezm? - the difficulties of classifying non-compliance in rural Uzbekistan, in: P. Sartori, and T. Trevisani, editors. Patterns of transformation in CentralAsia. Meltimi, Rome, Italy.

Wegerich, K. 2002. The role of elites in changing water institutions at the local level in Uzbekistan. Pages 19-29 in S. Neubert, W. Scheumann, and A. van Edig, editors. Reforming institutions for sustainable water management. German Development Institute, Bonn, Germany.

Wegerich, K. 2005. Institutional change in water management at local and provincial level in Uzbekistan. Peter Lang, Berlin, Switzerland.

Weinthal, E. 2001. Sins of Omission: constructing Negotiating Sets in the Aral Sea Basin. Journal of Environment and Development 10:50-79.

Weinthal, E. 2002. State making and environmental cooperation: linking domestic and international politics in Central Asia. MIT Press, Cambridge, USA.
WHO (World Health Organisation). 2006. Uzbekistan: country cooperation strategy at a glance. [online] URL: http://www.who.int/country focus/cooperation strategy/ccsbrief uzb en.pdf.

Wilhite, D.A.. 2005. The role of disaster preparedness in national planning with specific reference to drought. Pages 23-37 in M.K.V. Sivakumar, R.P. Motha, and H. Das, editors. Natural Disasters and Extreme Events in Agriculture.. Springer, Berlin, Germany.

World Bank. 2000. Social assessment and agricultural reform in Central Asia and Turkey. Technical paper 461. Europe and Central Asia Environmentally and Socially Sustainable Development Series, Washington, D.C., USA.

World Bank. 2003a. Drainage, Irrigation and Wetlands Improvement Phase 1 Project (DIWIP) for Uzbekistan. Project information document.

[online] URL: http://www-wds.worldbank.org/external/ default/WDSContentServer/WDSP/IB/2003/04/23/ $0000949460304090402258 /$ Rendered/PDF/multi0page. pdf

World Bank. 2003b. Uzbekistan: living standards assessment: policies to improve living standards (in two volumes): Volume I: summary report. World Bank, Washington, D.C., USA.

Yalcin, R., and P. P. Mollinga. 2006. Institutional transformation in Uzbekistan's agricultural and water resources administration: the creation of a new bureaucracy. Centre for Development Research, University of Bonn, Bonn, Germany.

Yalcin, R., and P. P. Mollinga. 2007. Water users associations in Uzbekistan: the introduction of a new institutional arrangement for local water management. Amu Darya case study - Uzbekistan. NeWater project. Zentrum für Entwicklungsforschung (ZEF), Bonn, Germany. 